\title{
1. The regulatory breakthrough of competition law: definitions and worries
}

\section{Mariateresa Maggiolino}

\section{INTRODUCTION}

Today, many antitrust scholars note the great change that competition law is undergoing. Some criticize the law's resemblance to economic regulation; others register with alarm its new regulatory nature. ${ }^{1}$ Yet, there is room to argue that the terms 'competition law' and 'economic regulation' are simple labels that relate to wavering ideals and a dynamic maze of diverse and overlapping phenomena (Section 2). Thus, to maintain that current competition law is taking the shape of a piece of economic regulation and support criticism of this transformation, we should address at least three questions. We should: (i) refer to some specific forms of economic regulation and competition law, so as to identify the many contours along which they can overlap or differentiate (Section 3); (ii) verify whether and how this multi-dimensional metamorphosis is taking hold in competition law (Section 4); and (iii) indicate what competition law loses - or is assumed to lose - because of the regulatory makeover it is purportedly undergoing (Section 5).

The chapter intends to accomplish these three goals without neglecting some critical thoughts about the idea that, unlike economic regulation, competition law is (or could be) a matter of pure (economic) technique, totally detached from value choices and political decisions (Section 6).

\footnotetext{
1 E.g. P. Areeda and H. Hovenkamp, Antitrust Law: An Analysis of Antitrust Principles and Their Application (Aspen Publ.: 3rd edn 2008) 770 et seq., and V. Korah, 'The Interface between Intellectual Property and Antitrust: The European Experience' (2002) 69 Antitrust L.J. 801, 832.
} 


\section{ECONOMIC REGULATION AND COMPETITION LAW - TWO WIDE-RANGING NOTIONS}

The mere idea that current competition law is taking the shape of a piece of economic regulation presupposes at least one insight: that competition law and economic regulation may be conceptualized as two separate phenomena that approach or move away from each other. However, as the following paragraphs show, since economic regulation is a multiform experience and competition law has no specific shape, there is not any $a$ priori division between the two.

\subsection{Economic Regulation as a Cubist Painting}

Only a cubist rendition would be capable of showing on a single plane what current economic regulation is - a kaleidoscopic object whose many facets result from more than thirty years of continuous theoretical and practical changes.

Since the late 1970s, when industrialized states embarked upon the so-called neoliberal programme, the experience of economic regulation that already characterized western states has been undergoing a surprising process of expansion and transformation ${ }^{2}$ that today is still in progress at national and international levels. ${ }^{3}$ While privatizing the assets

2 As a matter of practice, no form of substantial deregulation matched the privatization tide and the liberalization bandwagon that took the scene from the 1980s onwards. Rather, the years of neoliberalism witnessed a real process of 're-regulation' that involved states, markets and societies. See, e.g., I. Ayres and J. Braithwaite, Responsive Regulation: Transcending the Deregulation Debate (Oxford University Press 1992) 7. After all, scholars talk about the neoliberal 'programme' just in order to remark how the political practice significantly departed from the theoretical model that neoliberalism supported. For analogous opinions see S.K. Vogel, Free Markets, More Rules: Regulatory Reform in Advanced Industrial Countries (Cornell University Press 1996) and D. Levi-Faur and J. Jordana, 'The Rise of Regulatory Capitalism: The Global Diffusion of A New Order' (2005) 598 The Annals of The American Academy of Political and Social Sciences 12.

3 See, for instance, J. Braithwaite and P. Drahos, Global Business Regulation (Cambridge University Press 2000) 604, who argue that, although every single state exhibits specific regulatory courses and experiences, it would be a mistake to lose sight of the fact that many of the fundamentals of regulation are global. In addition, this homologation wave took place because, outside Europe and the United States, middle-sized countries are 'rule-takers' and because globalization has made states' territorial boundaries no longer coincide with the 
owned by key industries, liberalizing the provision of many goods and services and loosening their grip on tariffs, quotas, rates and market entrance, industrialized states repeatedly adopt a host of regulatory techniques to maintain a sort of arm's length oversight over certain activities and industries, such as transport and infrastructure; power, gas, water and postal services; communication and broadcasting; finance, pollution, public health, labour safety and product quality. ${ }^{4}$ In other words, while questioning the reasons justifying and explaining the very existence of regulation (economic regulation included), ${ }^{5}$ western countries did experience fifty years of 'regulatory capitalism' - they did become 'regulatory states and societies', ${ }^{6}$ willing to control the risks and

limits of political authority over economy and society. In this regard, see S. Strange, The Retreat of the State: The Diffusion of Power in the World Economy (Cambridge University Press 1996).

4 E.g. R. Baldwin, M. Cave and M. Lodge, 'Introduction: Regulation - The Field and the Developing Agenda' in R. Baldwin, M. Cave, M. Lodge (eds), The Oxford Handbook of Regulation (Oxford University Press 2010) 3, 7.

5 In brief, neoliberalism considered the market as the best tool to promote both private freedom and economic productivity. As a consequence, it affirmed the need to liberate individual entrepreneurial skills within an institutional framework characterized by, on the one hand, strong private property rights and free trade and, on the other hand, a minimum level of government actionism. In other words, neoliberalism held that governments should never interfere with the private order except in cases when, absent the market, they had to create property rights and distribute legal entitlements - as, for example, in areas such as water, education, health care, social security or environmental pollution. Neoliberalism held that the situation is different when markets already exist. Here any state intervention would cause two kinds of problems, at least: first, it would risk reducing efficiency, productivity and innovation, by harming the self-regulating mechanism that underpins markets; second, unless consistent with the Pareto criterion, state intervention would also collide with individuals' selfdetermination. Therefore, neoliberalism wanted sectors formerly run or regulated by the state to be turned over to the private sphere, freed from any interference, and left to competition. See, e.g., D. Harvey, A Brief History of Neoliberalism (Oxford University Press 2005); H. Overbeek and B. van Apeldoorn (eds), Neoliberalism in Crisis (Palgrave Macmillan 2012); H. Macartney, Variegated Neoliberalism: EU Varieties of Capitalism and International Political Economy (Routledge 2011); and G. Duménil and D. Lévy, The Crisis of Neoliberalism (Harvard University Press 2011).

6 In essence, the concepts of 'regulatory capitalism', 'regulatory state', and 'regulatory society' are analytical constructs seeking to catch the changes which occurred throughout the 1980s and 1990s. Notably, the first two focus, respectively, on the economic and institutional facets of the displacing process that 
hazards that economic activities entail, ${ }^{7}$ by implementing a new division of labour within the diverse components of the state and between the state and the society. ${ }^{8}$

For instance, without totally forgetting direct actions and design solutions, ${ }^{9}$ and following the motto 'steering is better than rowing', ${ }^{10}$ industrialized countries almost totally abandoned red-light prohibitions,

brought modern capitalist democracies away from public ownership and centralized planning, towards a new array of mechanisms of governance, steering and facilitation under the control of independent authorities. See, e.g., G. Majone, 'The Rise of the Regulatory State in Western Europe' (1994) 17 West Eur. Pol. 77; D Wincott, 'European Political Development, Regulatory Governance, and the European Social Model: The Challenge of Substantive Legitimacy' (2006) 12 Eur. L.J. 743, 750-51; J. Braithwaite, Regulatory Capitalism. How it Works, Ideas for Making it Work Better (Edward Elgar Publishing 2009) vii-viii; K. Yeung, 'The Regulatory State', in R. Baldwin, M. Cave and M. Lodge (eds), The Oxford Handbook of Regulation (Oxford University Press 2010) 64. The idea of the regulatory society, instead, is less focused on the relationship between states and citizens, but looks at co-coordinating, influencing and balancing interactions between actors and systems, and at the process of creating new patterns of interaction which enable social actors and systems to organize themselves. See, e.g., J. Black, 'Decentring Regulation: Understanding the Role of Regulation and Self-Regulation in a "Post-Regulatory" World' (2001) 54 Current Leg. Probs. 103.

7 M.K. Sparrow, The Regulatory Craft (Brookings Institution Press 2000); R. Baldwin and J. Black, 'Really Responsive Regulation' (2001) 71 Mod. L. Rev. 59 (2001); R.H. Thaler and C.R. Sunstein, Nudge (Yale University Press 2008); and C. Hood, H. Rothstein and R. Baldwin, The Government of Risk, Understanding Risk Regulation Schemes (Oxford University Press 2001) 3 and 29.

8 J. Braithwaite, 'The New Regulatory State and the Transformation of Criminology' (2000) 40 Brit. J. Crim. 222, 225; M. Power, Organized Uncertainty: Designing a World of Risk Management (Oxford University Press 2007) 188; C. Hood, O. James and C. Scott, 'Regulation of Government: Has It Increased, Is It Increasing, Should It Be Diminished?' (1999) 78 Pub. Admin. 283; and M. Moran, The British Regulatory State: High Modernism and Hyper Innovation (Oxford University Press 2003) 9-10.

9 'Direct actions' take shape when governments use their public resources to create what is materially necessary (such as premises or infrastructures) for the achievement of specific results. 'Design solutions', on the other hand, take place when governments intervene in market structure in order to prevent a specific mischief from arising.

10 E.g. D. Osborne and T. Gaebler, Reinventing Government: How the Entrepreneurial Spirit is Transforming the Public Sector (Addison-Wesley Publishing Company 1992) 25. 
command and control regulations ${ }^{11}$ for green-light orders, ${ }^{12}$ tax/subsidy and right/liability schemes, ${ }^{13}$ disclosure regimes, ${ }^{14}$ and some diverse combinations thereof. ${ }^{15} \mathrm{Via}$ varied forms of self-regulation, ${ }^{16}$ western

11 Command and control regimes take form when governments impose prohibitions and obligations by employing legal rules backed by administrative enforcement and penal sanctions.

12 E.g. C. Harlow and R. Rawlings, Law and Administration (Cambridge University Press 2009).

13 By and large, 'tax/subsidy, and right/liability schemes' pivot around the same idea: that governments may use different tools to affect the cost-benefit analysis that economic agents are assumed to develop for deciding whether to undertake a specific detrimental or beneficial behaviour. Within the 'tax/subsidy schemes' governments affect the cost-benefit analysis by allocating expenses and gains. Therefore, they impose negative taxes so as to discourage detrimental activities, or deploy grants, subsidies, forms of public compensation and social insurance to encourage beneficial practices. In contrast, within a 'right/liability scheme' governments affect the cost-benefit analysis by allocating property rights and contracts, or by designing liability, whereby different patterns of rules originate, respectively: either fluxes of expenses or fluxes of gains.

14 'Disclosure regulations' usually prohibit the supply of false or misleading information and require mandatory disclosure of some pieces of information towards consumers, public agencies or governmental officials. Systematic mechanisms for surveillance, public scrutiny and accountability, as well as codes of conduct, management systems, corporate reporting systems and third-party certification schemes, have thus become very popular. Today, indeed, 'big corporations are just as subject to red tape and excessive internal regulation as they are to external regulation'. See D. Levi-Faur and J. Jordana (n. 2 above) 21. In other words, re-regulation also witnessed a potent infiltration of public law values, like transparency, into the private ordering. See J. Freeman, 'Extending Public Law Norms Through Privatization' (2003) 116 Harv. L. Rev. 1285.

15 The so-called 'regulation by contract' could be a good example of that. Suppose that the state wants to guarantee a minimum wage. As with direct actions, government departments or agencies can use their wealth and spending powers to conclude contracts only with firms that will pay their employees the required minimum wage. In this way, the state can impose a regulatory standard across all firms contracting with it without employing a specific command, but by distributing legal entitlements (in this case, the contract), as the right/liability scheme would require.

16 Self-regulation may appear to lack any state involvement, but in reality: (i) it can be adopted in pursuit of public policy tasks; (ii) its process may be constrained by statutory rules or within authorization systems and other mechanisms of participation or accountability; and (iii) its rules may enjoy full legal force even when enacted by self-regulators. The latter, then, may address all the economic agents operating in a given industry, or just those that take part in the self-regulatory process; furthermore, they may discharge several tasks, from 
states focused less on mere deterrent and top-down approaches in favour of more persuasive and bottom-up strategies. ${ }^{17}$ Having acknowledged that citizens perceived their ministerial apparatuses as arbitrary and technocratic, they delegated regulatory functions not only to independent authorities - whose transparency and social accountability were however to be improved ${ }^{18}$ via meta-regulation ${ }^{19}$ - but also to third-party nongovernmental bodies such as corporations' gatekeepers, industrial associations or international networks of experts. ${ }^{20}$ In sum, during half a

the promulgation of rules, to the enforcement of these on the ground, to the monitoring of the whole regulatory process. For instance, Braithwaite (n. 8 above) 231 argues that the proliferation of new self-regulatory techniques is a consequence of the development of more complex and globalized economies.

17 Indeed, according to the so-called 'responsive regulation' and 'smart regulation' models, governments should pursue firms' compliance through persuasion. For this purpose, self-regulation and regulations involving third entities, like professional bodies and industry associations, should be considered as the most effective tools. See, in this regard, N. Gunningham and P. Grabosky, Smart Regulation (Clarendon Press 1998).

18 E.g. M. Power, The Audit Society (Oxford University Press 1997); M. Power, 'The Audit Society - Second Thoughts' (2000) 4 Int'l J. Accounting 111; M. Power, 'Evaluating the Audit Explosion' (2003) 25 L. \& Pol. 185 (using the expression 'audit society' to claim how governments had extended financial auditing and other monitoring mechanisms, such as ethics codes, across a variety of regulatory matters like health care, education, finance and welfare, in order to increase the (real and perceived) accountability of their own administrations. Thus, the author argues, 'formalized accountability', i.e. the kind of accountability that could be formally verified and certified, has become a 'ruling principle' for the whole society, i.e. for the job of regulators as well as for the claims of the regulatees). In addition, see C. Hood, O. James, G. Jones, C. Scott and T. Travers, Regulation Inside Government: Waste-Watchers, Quality Police and Sleaze-Busters (Oxford University Press 1999) (creating the label 'Regulation Inside Government' to address the new methods of control under which a range of independent regulatory agencies could check their own quality and effectiveness).

19 The expression 'meta-regulation' addresses just the case of internal regulatory techniques adopted by regulators, regulatees and other subjects (such as gatekeepers, private parties, whistleblowers, or regulated companies' employees) to monitor their compliance with the given regulation and thus to guarantee a greater transparency and social accountability. D. Levi-Faur and S. Gilad, 'The Rise of the British Regulatory State: Transcending the Privatisation Debate' (2004) 37 Comp. Pol. 105, 113; C. Parker, 'Regulator-Required Corporate Compliance Program Audits' (2005) 25 L. \& Pol. 221; C. Coglianese and D. Lazer, 'Management Based Regulation: Prescribing Private Management to Achieve Public Goals' (2003) 37 L. \& Soc. Rev. 691.

20 Levi-Faur and Jordana (n. 2 above). 
century western states created many and various pieces of regulation that promoted the achievement of different economic, political and social goals in relation to specific sectors and issues, while at the same time combining the job of public and private enforcers, implementing legal, social and economic rules, imposing proscriptions as well as prescriptions and affecting such diverse targets as market structure, legal entitlements, economic incentives, information spread and firms' behaviour.

As a consequence, our current perception of economic regulation cannot be anything but wide and far-reaching ${ }^{21}$ - so wide and farreaching that even competition law can be soundly characterized as a piece of economic regulation. For instance, it can be deemed as a market-harnessing mechanism that, in the interest of the public, realizes a form of legal control on businesses. ${ }^{22}$ Thus, to argue that current competition law is today taking the shape of a piece of economic regulation does not make much sense. In order to talk about 'the regulatory breakthrough' of competition law, we need to put aside any description of what happened in the de-regulation era, as well as any resulting broad and multiform notion of economic regulation. We need to consider a narrower, more specific and detailed conceptualization - in fact, a historically determined conceptualization - of what economic regulation is.

21 To be sure, this broad perception of what economic regulation is should not astonish. Actually, the inability to understand economic regulation is inherent in the very definition of what 'the market' is. On the one hand, the market itself can be regarded as the result of choices and decisions that take the form of legal and social rules, so that almost any rule could be said to affect market practices, even contract, criminal and tort rules that set the general standard of private negotiations. On the other hand, because of the so-called 'commoditization approach', any practice can be conceptualized as an 'economic practice', i.e. as behaviour that requires and entails the use of something that we can commercialize in exchange for something else. Therefore, almost any behaviour subject to rules could be deemed as an economic practice.

22 E.g. R. Baldwin, M. Cave and M. Lodge, Understanding Regulation: Theory, Strategy and Practice (Oxford University Press: 2nd edn 2012) 114 et seq. On the convergence between competition law and economic regulation see C. Leslie, 'Antitrust Law as Public Interest Law' (2013) 2 UC Irvine L. Rev. 885; M. Handler, 'Regulation Versus Competition' (1973-1974) 43 Antitrust L.J. 277; and U.S. Court of Appeals, Town of Concord v. Boston Edison Co., 915 F.2d 17, 22 (1st Cir. 1990), cert. denied, 499 U.S. 931 (1991), where Justice Breyer observed that economic regulation and antitrust law pursue 'similar goals - i.e., low and economically efficient prices, innovation, and efficient production methods'. 


\subsection{Competition Law as a Liquid Concept}

Notwithstanding the few US and EU provisions that directly associate competition law with anticompetitive arrangements and monopolistic conduct, our conception of what competition law is has changed over time according to the different goals that policy makers and scholars have assigned to it. ${ }^{23}$ Think, for example, of the rules applied to monopolistic conduct. During different periods, both US courts and EU antitrust institutions have interpreted and enforced them as if competition law was called to: (i) protect small businesses against the 'dictatorship' of big, concentrated and vertically integrated businesses; (ii) ensure fairness, justice, equity and redistribution; (iii) guarantee the process of competition; (iv) preserve economic welfare; and, in the sole case of the European Union, (v) support the creation of the Single Market. ${ }^{24}$

More generally, over the past fifty years or so antitrust scholars and practitioners have been divided between those who think that competition law can be used aggressively to achieve perfectly competitive markets and those who believe that, in practice, competition law can make only a modest contribution to the goal of protecting effective competition. ${ }^{25}$ Indeed, competition law provisions are so flexible and open-ended that they can mirror - and indeed have mirrored - the cultural insights as well as the political concerns and values of our social and political communities. ${ }^{26}$ For example, the transatlantic past preference for the welfare of small businesses (and, hence, for dominant firms' rivals) was fed by the laissez faire alarm about bigness as such, the economic misconception that good business performances rest only with non-concentrated markets, and by the concern that economic power concentration would

23 See R. Bork, The Antitrust Paradox (Simon \& Schuster 1978) 50 (arguing that 'antitrust policy cannot be made rational until we are able to give a firm answer to one question: What is the point of the law - what are its goals? Everything else follows from the answer we give').

24 E.g. M. Maggiolino, Intellectual Property and Competition Law: A Comparative Economic Analysis of US and EU Law (Edward Elgar Publishing 2011) 63-71; M.S. Gal, 'Monopoly Pricing as an Antitrust Offense in the U.S. and the EC: Two Systems of Belief About Monopoly?' (2004) 49 Antitrust Bull. 343.

25 R.A. Cass, 'Competition in Antitrust Regulation: Law Beyond Limits' (2010) 6 J. Comp. L. \& Econ. 119, 120.

26 A.I. Gavil, W.E. Kovacic and J.B. Baker, Antitrust Law in Perspective: Cases, Concepts and Problems in Competition Policy (West Law 2008) 16, argue that even when it comes to the identification of the economic goals of competition law, "we look to what society expects to achieve through the operation of private markets'. 
impair free markets and democracy. ${ }^{27}$ Likewise, the currently dominant idea according to which competition law consists of a set of legal rules that aims at preventing those business practices that may harm economic welfare - never mind whether total or consumer welfare ${ }^{28}$ - can be traced back to the neoliberal programme that the Chicago School embraced in the 1970s. ${ }^{29}$

In sum, competition law is a liquid concept. Therefore, in order to conceptualize the regulatory breakthrough of current competition law we must, first, assume that there exists a form of competition law - perhaps just a theoretical one - whose shape has nothing to do with a piece of economic regulation, and, second, verify that the shape of current competition law is taking on some regulatory contours. Further, if we want to explain the alarm that this regulatory transformation of competition law is producing, we must also show whether and how competition law loses something important when it is poured into a 'regulatory container'.

\section{THE POSSIBLE REGULATORY CONTOURS OF COMPETITION LAW}

Behavioural and social phenomena are often understood 'in terms of a purposeful selection of facts from a far wider range of ways of looking at things' ${ }^{30}$ Therefore, in order to grasp the terms under which competition law can become a regulatory enterprise - or a more regulatory enterprise - the following paragraphs go to the antipodes. They briefly consider and compare two extreme species of economic regulation and competition

27 D.I. Baker and W. Blumenthal, 'Ideological Cycles and Unstable Antitrust Rules' (1986) 31 Antitrust Bull. 323; W. Möschel, 'Competition Policy from an Ordo Point of View', in A. Peacock and H. Willgerodt (eds), German Neoliberals and the Social Market Economy (Macmillan 1989) 146; E.T. Sullivan, The Political Economy of the Sherman Act: The First One Hundred Years (Oxford University Press 1990); E.M. Fox, 'We Protect Competition, You Protect Competitors' (2003) 26 World Comp. 149, D.J. Gerber, Global Competition: Law Markets and Globalization (Oxford University Press 2010).

28 L. Kaplow, 'On the Choice of Welfare Standards in Competition Law', in D. Zimmer (ed.), The Goals of Competition Law (Edward Elgar Publishing 2012) 3 .

29 M. Motta, Competition Policy: Theory and Practice (Cambridge University Press 2004) 30.

30 R. Popkin, 'The Function of Definitions in Social Science' (1943) $40 \mathrm{~J}$. Phil. 491, 495. 
law, that is to say: (i) those sector-specific, rate-and-entry pieces of economic regulation that the US government actually 'enforced' in the United States until the end of the 1960s; and (ii) the notion of competition law that the Chicago School 'theorized' at the beginning of the 1970s. Indeed, these heterogeneous examples of economic regulation and competition law are optimal 'sparring partners' to reveal the possible lines along which competition law can assimilate to, or differentiate itself from, a piece of economic regulation.

\subsection{Government ‘Actionism' and Sector-Specific, Rate-and-Entry Regulations}

Since the second half of the 19th century and, in particular, for the period from the 1930s to the 1970s, in the United States the term "economic regulation' was often used to denote what we today call command and control regimes. ${ }^{31}$ By using rigid rules backed by administrative enforcement and penal sanctions, independent governmental agencies presided over firms' market actions in many sectors, such as trucking, airlines, telephone services, electricity, radio, television and natural gas. These agencies could prohibit certain forms of conduct, but also demand some positive actions by, say, prescribing the goods and services to be rendered, indicating the market to be served, deciding when plants needed to be built or modernized or determining how much should be invested in developing new technologies. Furthermore, those independent agencies could lay down conditions for entry into a sector, by determining which firms or individuals (or types thereof) were allowed to engage in which activities, and by controlling not only the quality of a production technique or of a service, but also the allocation of input and output, as well as the prices charged to consumers, or the profits made by enterprises.

In brief, by the end of the 1960s the regulatory programmes implemented in the United States required independent authorities to act for a better future - i.e. to promote economic welfare, economic growth and

31 After the end of the Second World War, in the United States and in European countries the label 'economic regulation' was used to describe diverse phenomena. Especially in Europe, where governments preferred to do the job themselves instead of assigning it to bodies of commissioners, the expression economic regulation covered cases of industrial reorganization and planning as well as cases of national states acting as 'entrepreneurs'. See, e.g., D. Swann, The Retreat of the State: Deregulation and Privatization in the UK and US (Harvester-Wheatsheaf 1988) 28. 
the public interest - by imposing on firms what conduct to undertake and by taking in advance manifold detailed decisions on the market equilibria that these independent authorities believed were to be achieved. These programmes were made up of proscriptions as well as prescriptions, whereby public agencies were entitled to fully decide, manage and control private affairs. ${ }^{32}$

\subsection{Neoliberalism and Chicagoan Conception of Competition Law}

At the beginning of the 1970s, the Chicagoan conception of competition law was totally defiant of government 'actionism'. Because of its support for neoliberalism, the Chicago School called for the abolition of competition law, by endorsing full faith in the automatic free-market system it maintained that the government was the problem and not the solution.

Then, if competition law was to be somehow tolerated, antitrust enforcers were to play a very residual role. They had to prohibit the sole business practices that harmed the competitive status quo, i.e. that produced a negative impact on the 'natural functioning' of the market. ${ }^{33}$ Further, enforcers had to identify the 'natural functioning' of the market by looking at the performance of total welfare, i.e. in full accordance

32 S. Breyer, 'Regulation and Deregulation in the United States: Airlines, Telecommunications and Antitrust', in G. Majone (ed.), Deregulation or Re-Regulation (Frances Pinter 1990) 7-8 and 12-15. According to Breyer, 'in the United States - at least "economic regulation" broadly conceived - typically refers to governmental efforts to control individual price, output, or product quality decisions of private firms, in an avowed effort to prevent purely private decision-making that would take inadequate account of the "public interest".

33 In sum, the contrast between sector-specific, rate and entry regulations and Chicagoan antitrust law can be analogized to that between a steady cure aimed at treating a chronic disease and a surgical intervention adept at excising specific illnesses. For this analogy see F.M. Scherer and D. Ross, Industrial Market Structure and Economic Performance (McGraw Hill 1990) 12. Furthermore, see A. Devlin, 'Antitrust as Regulation? (2012) 49 San Diego L. Rev. 823, 825 and 830; N.B. Grzegorek, 'The Price of Admission: How Inconsistent Enforcement of Antitrust Laws in America's Live Entertainment Sector Hurts the Average Consumer' (2010) 44 J. Marshall L. Rev. 261, 269; R.A. Cass, 'Competition in Antitrust Regulation: Law beyond Limits' (2010) 6 J. Comp. L. \& Econ. 119, 122; A.D. Melamed, 'Antitrust: The New Regulation' (1995-1996) 10 Antitrust 13; and S. Breyer, Regulation and its Reform (Harvard University Press 1982) 156-57. 
with the main teachings of mainstream economics, ${ }^{34}$ and without pandering to political ideals or specific interests. In addition, and here, too, in order to limit government 'actionism', the Chicago School wanted antitrust enforcers to intervene only when there was no risk of making false positive mistakes. Therefore, they had to take their 'hands off' of any case, such as the monopolization cases, where the alleged harmful effects were somehow questionable and speculative. Also, just to control the negative consequences that could follow a wrong intervention, their remedies had to consist in mere cease-and-desist orders and injunctions, ${ }^{35}$ as the traditional US model of private enforcement envisaged. ${ }^{36}$

In brief, the overall conceptualization that the Chicago School made of competition law was thought to limit as much as possible the interference of public powers in private affairs. The neoliberal programme, indeed, assumed that the market mechanism made up of preferences, choices, transactions and contracts was alone capable of guaranteeing economic welfare, individuals' self-determination and the aggregate sum of subjective value satisfactions. ${ }^{37}$

34 M. Maggiolino, 'The Economics of Antitrust Law and Intellectual Property Rights', in S. Anderman and A. Ezrachi (eds), Intellectual Property and Competition Law: New Frontiers (Oxford University Press 2011) 73.

35 E.g., D.L. Rubinfeld, 'On the Foundations of Antitrust Law and Economics', in R. Pitofsky (ed.), How the Chicago School Overshot the Mark (Oxford University Press 2008) 51; F. Easterbrook, 'The Limits of Antitrust' (1984) 63 Tex. L. Rev. 1, 3.

36 The enforcement of U.S. competition law is mainly up to judges. Therefore, in the United States antitrust enforcers are thought to be much more passive than regulators. Consider, for example, that judges are to decide only the cases that come before them, whereas regulators control their own agendas and can leap from one spot to another within the whole sector over which they preside. In addition, because of the rules of the adversarial system, it is the conflict between plaintiffs and defendants that shapes judges' decision-making. In contrast, reciprocal consent and negotiation are the usual 'key words' of the decisionmaking process that regulators develop. Finally, courts are a poor forum for reflecting and balancing democratic values, whereas regulators are institutionally expected to reconcile diverse interests and values.

37 R. Nozick, 'Distributive Justice' (1973) 1 Phil. \& Pub. Aff. 3; F. von Hayek, The Constitution of Liberty (University of Chicago Press 1960). In addition see Northern Pacific Ry. v. United States, 356 U.S. 1, 4 (1958) (arguing that such a conception of antitrust law rests 'on the premise that the unrestrained interaction of competitive forces will yield the best allocation of our economic resources, the lowest prices, the highest quality and the greatest material progress, while at the same time providing an environment conducive to the preservation of our democratic political and social institutions'). 


\subsection{So Far, So Close}

In the light of the above terms of comparison, we can elicit many of the conditions under which the shape of competition law can acquire some regulatory contours.

In general, the 'regulatory metamorphosis' of competition law happens - or starts happening - when competition law changes its goals, that is to say, when it does not limit itself to protecting total welfare, but pursues political and social aims, or even an economic goal other than the mere protection of the market's 'natural functioning'. For example, antitrust law may work to set the stage for better market equilibria and for higher levels of competition - it can work to maximize total and/or consumer welfare.

In the latter scenario, then, antitrust law changes for another reason because it modifies its targets. It focuses not only on those business practices that can harm total welfare, but also on the structure of the markets at stake, on the existing distribution of incentives and legal entitlements, on the spread of information and on business practices that do not maximize total and consumer welfare. ${ }^{38}$ In other words, a form of competition law that pursues different goals also puts the spotlight on different economic variables.

When antitrust enforcers modify their targets, they accordingly use different tools and approaches - they impose not only bans, but also positive obligations establishing what economic agents should do in order to set the stage for better market equilibria. ${ }^{39}$ They abandon a mere $e x$ post, backward-looking and facts-based attitude focused on the protection and the restoration of the status quo, to endorse a more ex ante,

38 The focus on a specific market makes antitrust rules less universal than they should be according to the Chicago archetype. The latter wants antitrust law to catch any economic agent, just considering it as the 'seller' or the 'purchaser' of the product in question and, thus, regardless of its identity, its 'history of meritorious competitive acts', or its social status. A more regulatory conception of antitrust law, in contrast, allows enforcers to deal with the specific protagonists of the market at stake; their reasons, interests, merits and faults.

39 A more regulatory approach to antitrust law asks the latter to identify what the optimal market equilibrium should be and to target those economic variables and procompetitive activities that can facilitate its achievement over time. See, e.g., D.W. Carlton and R.C. Picker, 'Antitrust and Regulation' (2006), 3, available at: http://ideas.repec.org/p/nbr/nberwo/12902.html (accessed 9 March 2014). 
forward-looking and theory-laden position aimed at fostering market development. ${ }^{40}$

In brief, competition law may experience a regulatory breakthrough as long as it moves away from the minimalist archetype of the Chicago School - away from its goals, targets, tools and approaches. Or, at least, this is the 'theoretical framework' into which a regulatory transformation of competition law can be inserted.

\section{THE TERMS OF THE PRESENT' REGULATORY METAMORPHOSIS' OF COMPETITION LAW}

The above theoretical map of what might give a regulatory mould to competition law does not necessarily mean that such a transformation is actually taking place. Indeed, the mere existence of this theoretical map does not necessarily imply that this transformation has ever taken place the Chicagoan notion of antitrust law is still influencing the US and EU practice, but it has never been fully endorsed, especially in the European Union. Therefore, one could argue that competition law has always been a sort of regulatory enterprise.

However, this is not the place to make such a historic analysis. Moreover, this is not the place to discuss the many circumstances in which current US antitrust law and EU competition law look like a piece of economic regulation - the following chapters are devoted to thoughtful analysis of this twofold subject.

Nevertheless, some clear facts suggest that today's competition enforcers - and especially the EU Commission - are available to play a more active role in promoting the maximization of economic welfare (i.e. in pursuing a different goal), by affecting not only business conduct, but

40 While antitrust law - and, in particular, the provisions about anticompetitive arrangements and monopolistic conduct - is thought to work as an ex post means, i.e. as a surgeon's knife that eradicates the evil that is actually plaguing the market, economic regulation is meant to serve as an ex ante tool, i.e. to dictate in advance what prophylaxis the market should follow to avoid any pain that medicine says will or could occur. In particular, while the Chicagoan conception of competition law cannot but be backward-looking and fact-based, i.e. focused on what the involved firms did (or are doing) and on what specific market scenarios characterized (or still characterize) their acts, sector-specific, rate-and-entry regulations are also forward-looking and theory-laden, i.e. focused on what firms are expected to do, and on what events are expected to happen according to the economic theory called on to explain how markets function and develop. 
also market structures, the existing economic incentives, and the given legal entitlements (i.e. by targeting different variables). Hoping to set the stage for better market equilibria (i.e. endorsing a more ex ante approach), current antitrust enforcers are now more willing than they were in the past to 'negotiate' the content of their decisions (i.e. they are less subordinate to the results coming from the adversarial system) and to use sophisticated economic models ${ }^{41}$ to make educated guesses about future market developments (i.e. they are liable to be more theory-laden and to carry their assessment into the long run). Not by chance, indeed, do expressions such as 'competition promotion', 'negotiated remedies', 'forward-looking decisions', 'market reorganization' and 'continuous monitoring' belong to the vocabulary of today's antitrust enforcers. ${ }^{42}$ For example, consider what the EU Commission does in duty-to-deal cases such as the Microsoft saga. ${ }^{43}$ In these cases, for the sake of what the Commission considers to be the public interest, it decides how to reshape property rights and distribute the incentives to compete and innovate among the players of the industries at stake. Thus, in duty-to-deal cases the Commission clearly acts as a regulator: it establishes where to drive markets on the basis of specific economic theories, such as the defensive leverage theory; ${ }^{44}$ it endorses a clear forward-looking perspective; and it imposes not only equitable relief and cease-and-desist orders, but also positive obligations impinging on structural variables. In so doing, the Commission takes into account the 'industrial identities' of the involved firms, that is to say, their history of meritorious competitive acts, whether

41 Melamed (n. 33, above) 15, argues that 'today's economists - using the tools of both price theory and game theory - are able to imagine all sorts of anticompetitive strategies, private market failures, and remedies for them. As a result ... government antitrust officials sometimes ask, not whether the defendant violated a legal norm, but whether constraining the defendant's use of its property might improve or ensure its contribution to consumer welfare. In effect, economic analysis lends itself to a kind of prospective analysis that is in substance a regulatory inquiry, not a law enforcement inquiry.'

42 E.g. M. Szydło, 'Sector-Specific Regulation and Competition Law: Between Convergence and Divergence' (2009) 15 Eur. Pub. L. 257.

43 E.g. M. Maggiolino (n. 24 above) ch. 5.

44 See, in general, R. Cooper Feldman, 'Defensive Leveraging in Antitrust' (1990) 87 Geo. L. J. 2079, and, in relation to the Microsoft saga, C. Genakos, K. Kühn and J. Van Reenen, 'Leveraging Monopoly Power by Degrading Interoperability: Theory and Evidence from Computer Markets' (2011) National Bureau of Economic Research, Working Paper 17172, available at: http://www.nber.org/ papers/w17172 (accessed 1 September 2014). 
they were previous state monopolists, or whether they deserve their market position or their intellectual property rights. ${ }^{45}$

In addition, consider the more frequent commitment decisions. They grant a great regulatory leeway to antitrust enforcers. ${ }^{46}$ Indeed, in issuing commitment decisions the EU Commission - not unlike the US agencies that adopt consent decrees - works as a mediator between the parties, knowing their diverse interests and facilitating the negotiation and conciliation of their opposite positions.

Finally, do not forget that, according to some scholars, any antitrust agency or authority that adjudicates a case adopting the rule of reason is actually acting as a regulator that substitutes its economic evaluations for those of entrepreneurs. Namely, establishing whether a restriction is reasonable entails, inter alia, considering whether there could be a less restrictive alternative, that is to say, making an educated guess about how best to achieve a better market equilibrium: by using the option chosen by the entrepreneur or by using another option that the antitrust agency or authority envisages. ${ }^{47}$

In sum, there is room to argue that current competition law does not have the shape of the Chicago archetype. And this creates a sort of alarm.

\section{THE REASSURING NATURE OF THE CHICAGO ARCHETYPE}

Probably, antitrust scholars are very fascinated by the Chicagoan notion of competition law because they were trained during the years of the Chicago bandwagon. Probably - and this is my personal belief - their diffidence towards a more 'regulatory approach' to competition law arises from the reassuring nature of Chicago antitrust, i.e. from the fact that the Chicago concept of competition law shelters - or seems to shelter -

45 Often it has been noticed that those firms that achieve a dominant position because of network effects do not really deserve it - see, e.g., G.J. Werden, 'Network Effects and Conditions of Entry, Lessons from the Microsoft Case' (2001) 69 Antitrust L.J. 87 - or that some of the IPRs used to defend a dominant position should have not been granted in the first place - see e.g. I.S. Forrester, 'EC Competition Law as a Limitation on the use of IP Rights in Europe: Is there Reason to Panic?', in C. Ehlermann and I. Atanasiu (eds), European Competition Law Annual 2003: What is an Abuse of Dominant Position? (Hart Publishing 2003) 506.

${ }^{46}$ E.g. H. First, 'Is Antitrust “Law”?' (1995-1996) 10 Antitrust 9; Melamed (n. 33 above).

47 E.g. Devlin (n. 33 above) 837. 
enforcers from the risk of enjoying too much discretion. Let me briefly elaborate the details of the argument.

Basically, regulators enjoy a great leeway. They can establish (or interpret) what the public interest is and what rules could help to pursue it. ${ }^{48}$ Yet, information asymmetries as to present market scenarios, as well as limited knowledge as to possible and future market developments, inexorably affect regulators' ability not only to identify what the optimal market equilibrium should be, but also to determine what changes to market structure, initial endowments and original entitlements should be continuously promoted so as to accommodate the dynamic achievement of this equilibrium. Therefore, regulators may make mistakes in defining (or interpreting) their goals and in elaborating and applying the rules that, over time, should allow these goals to be accomplished.

In addition, the very same ignorance that increases the risk of making mistakes exposes regulators to another twofold risk - that of being manipulated and that of making value choices to the detriment of individuals' self-determination. For example, technocrats themselves may try to influence the notion of public interest in order to preserve or expand their power and jurisdictional turf. In this way, they can deepen their intervention into the affairs of the regulated enterprises and control issues and firms more than necessary. ${ }^{49}$ Or, looking for better information to draw up and enforce their rules, regulators can be captured ${ }^{50}$ - they may fall under the spell of the regulatees and, thus, consider some rules to be in the public interest, although in fact these rules fulfil the interest of specific groups of firms. ${ }^{51}$ And even away from these species of

48 For the controversial notion of public interest see, e.g., M. Feintuck, 'Regulatory Rationales Beyond the Economic: In Search of the Public Interest' in Baldwin, Cave and Lodge (eds) (n. 6 above) 39.

49 E.g. L. Loevilger, 'Regulation and Competition as Alternatives' (1966) 11 Antitrust Bull. 120.

50 Consider that the so-called 'capture theory', together with the 'public choice' and 'special interest group' theories, are generally associated with what is called the 'economic theory of regulation' elaborated within the walls of the same Chicago School that forged the current notion of competition law. See, e.g., S. Peltzman, 'Towards a More General Theory of Regulation' (1976) 19 J. L. \& Econ. 211.

51 J. Stigler, 'Theory of Economic Regulation' (1974) 2 Bell J. Econ. 3; R.A. Posner, 'Theories of Economic Regulation' (1974) 5 Bell J. Econ. 335; W.A. Jordan, 'Producer Protection, Prior Market Structure and the Effects of Government Regulation' (1992) 15 J. L. \& Econ. 151. In particular, scholars have elaborated a number of versions of the capture theory. The 'bribery' and 'revolving doors' models rely on the idea of a regulator induced to be lenient 
manipulations, since regulators have no objective standard to establish what the public interest is and what rules could help in pursuing it, their decisions may, however, side with specific visions of the world. Their decisions are not neutral - they are value choices, at least partially.

In contrast - and in a very reassuring way - the Chicago conception of competition law would have antitrust enforcers act like mere technicians who, by doing only what the economic technique tells them to do, can stay away from any form of discretion and are thus sheltered from mistakes, manipulations and conflicts of interests and values. Namely, suppose that the market is a cosmos - i.e. a "natural, spontaneous and necessary' order governed by universal, unchangeable and objective rules that technicians may know and calculate. ${ }^{52}$ Assume, then, that economics is the domain of these rules - it is like a hard science that describes what the 'natural' functioning of the market is. In the light of these assumptions, as long as antitrust law 'translates' these economic rules into the legal realm - as the Chicago School wanted it to do - the risk of making mistakes is low and there is little room for manipulations, conflicts of

with respect to regulated firms through offers of monetary transfers or future employment. Other models assume regulator-regulatee proximity as the trigger that induces leniency. The 'life-cycle' explanation suggests that, after great expense of effort and resources to be independent, lonely and isolated regulators become the protectors of the regulated industry; the 'interest-group' accounts stress the extent to which regulators can be influenced by the claims coming from either political or powerful business lobbies.

52 F. von Hayek, The Confusion of Language in Political Thought: With Some Suggestions for Remedying It (The Institute of Economic Affairs 1968) 15 and 28: ' $[\mathrm{t}]$ he ordered structure which the market produces is ... not an organization but a spontaneous order or cosmos' subject to nomoi, by which term 'we shall describe a universal rule of just conduct applying to an unknown number of future instances and equally to all persons in the objective circumstances described by the rule, irrespective of the effects which observance of the rule will produce in a particular situation ... Such rules are generally described as "abstract" and are independent of individual ends. They lead to the formation of an equally abstract and end-independent spontaneous order or cosmos.' In particular, von Hayek contrasts this with taxis, i.e. an artificial order that results from political choices, tries to pursue specific objectives, and is subject to specific rules named thesis. Indeed, 'we shall use thesis to mean any rule which is applicable only to particular people or in the service of the ends of rulers. Though such rules may still be general to various degrees and refer to a multiplicity of particular instances, they will shade imperceptibly from rules in the usual sense to particular commands. They are the necessary instrument of running an organization or taxis.' 
interests and diverse political views. ${ }^{53}$ In other words, as long as antitrust enforcers pursue the protection of total welfare by forbidding the sole business practices that mainstream economics say harm it, their approach and tools are so tailored to the evil to be removed that they are little suited for anything else.

True, one could argue that economics does not always supply definitive answers to be easily translated into the antitrust realm. Consider, for example, the case of antitrust decisions dealing with the duration and scope of monopolies and IPRs. Economics does not know where to strike the proper inter-temporal balance between creating and disseminating the incentives to compete and innovate. In such a situation, hence, the lack of an economic rule to be translated into the legal field could open the gate to mistakes, manipulations and value choices.

To rebut this argument the Chicago School would argue that in those cases antitrust enforcers must take their hands off any negotiation or any other intrusive decision envisaging what the public interest could be. In the absence of any clear-cut economic rule to be translated into the antitrust realm, leaving things as they are, leaving markets free to polish themselves, should be the best way to limit the risks of prosecuting harmless conduct, of being at the mercy of a specific group of interests and of espousing a particular vision of the world.

In brief, the less, the better. By conditioning antitrust enforcement to what mainstream economics teaches, and by supporting the 'hands-off approach' any time economics is not capable of formulating precise economic rules to qualify business behaviour, the Chicago archetype claims to limit as much as possible enforcers' discretion and, as a consequence, the risks of making mistakes, of being manipulated, and of making value choices. In other words, the more competition law limits itself to replicate the most certain teachings of economics, the more it becomes a safe game - i.e. a matter of 'truth' - and this is something that

53 This reproduces in the legal field the idea that microeconomics, in contrast to macroeconomics, identifies a scientific endeavour devoid of politics. Since the mid-1930s 'the high priests and authorities of economics pronounced Anathema, in the sacred name of Science, on value judgments. ... The Anathema on value judgment was obscurantist. The obeisance to the positivist rules of science was epistemologically incongruous and self-deceiving. The economic discourse could not and did not dispense with value judgement': R.A. Solo, 'Values and Judgments in the Discourse of the Sciences' in R.A. Solo and C.W. Anderson (eds), Value Judgment and Income Distribution (Praeger 1981) 31 and 34; and R.J.R. Peritz, Competition Policy in America, 1888-1992: History, Rhetoric, Law (Oxford University Press 1996) 241. 
no form of regulation, and no form of a more regulatory approach to competition law, can ever be. ${ }^{54}$

Yet, this narrative is misleading.

\section{DEBUNKING THE REASSURING NATURE OF THE CHICAGO ARCHETYPE}

It may actually happen - as the Chicago School maintains - that some economic rules (and their layman rehashes) offer a true description of how markets work. In this case, anchoring antitrust law to economics really limits enforcers' discretion as well as the consequences that this discretion is said to bring about in terms of mistakes, manipulations and value choices.

Yet, even setting aside the case of economic rules that are too sophisticated to offer a realistic description of how competition develops, ${ }^{55}$ there are economic rules that, though correct and sound, depend so much on some detailed hypotheses that they do not offer one single applicable conclusion for the specific antitrust case at stake. ${ }^{56}$ Moreover, as seen above in the discussion about the duration and scope of

54 G. Minda, "Towards a More "Just" Economics of Justice - A Review Essay' (1989) 10 Cardozo L. Rev. 1855, 1857 (addressing competition law as a 'technocratic legal discourse based on the conceptual framework of market exchange') and D.N. McCloskey, 'The Rhetoric of Law and Economics' (1988) 86 Mich. L. Rev. 752, 760-67 (arguing that detachment from value judgments, i.e. objectivity of observations and explanations, is one of the requirements of sciences and, hence, of those social disciplines that try to be scientific). Interestingly enough, Peritz attested to Posner just this attempt to morph its ideology into a science. Peritz (n. 53 above) at 238, argues that 'Posner was obsessed with convincing his readers that his project was positive, not normative; scientific, not ideological. He was not arguing, he insisted, that economic efficiency ought to be the beacon guiding public policy and legal rule-making. He was, instead, testing a hypothesis, a scientific theory, about the way human institutions actually work.'

55 M. Blaug, 'Ugly Currents in Modern Economics' (1997) 17 Pol. Options 3 (modern economics 'has increasingly become an intellectual game played for its own sake and not for its practical consequences for understanding the economic world'); T. Lawson, 'Mathematical Modeling and Ideology in the Economics Academy: Competing Explanations of the Failings of the Modern Discipline?' (2012) 1 Econ. Thought 3.

56 This is the case of the most recent, and very complicated, industrial organization models implementing game theory. 
monopolies and IPRs, there are cases where no economic rule can definitively establish what the 'natural functioning' of the market is.

Hence, in these two cases, any antitrust decision translating one of those economic rules into the legal field is no longer a matter of pure technique. ${ }^{57}$ When there is no single and definitive economic rule to implement, antitrust enforcers also enjoy discretion - an amount of discretion that, notably, even the Chicagoan 'hands-off approach' cannot manage in a technical way.

Indeed, the Chicagoan 'hands-off approach' shelters the system from manipulation because it does not leave any room for negotiation. Yet, it is not error-free, because if the natural course of the market is unknown, leaving things as they are can be as wrong as changing them. Moreover, the 'hands-off approach' is not value-free for at least two reasons. First, assuming that false positive mistakes are more serious than false negative mistakes means siding with the (neoliberal) belief that markets can refine themselves better than any government action can. Second, when dealing with a specific case, leaving things as they are may mean siding with specific interests and values - those interests and values that the particular status quo at stake reflects. For example, the choice not to impose a duty to deal on monopolists holding IPRs endorses two questionable theses - that judges and antitrust administrative authorities cannot second guess (IP) legislators' choices, and that the overall level of innovation increases leaving the lead to dominant IP holders rather than to tiny followers.

Besides, to test the neutrality claim of the Chicago School against more radical observations, ${ }^{58}$ it must be acknowledged that, as such, the

57 A. Devlin and M. Jacobs, 'Antitrust Divergence and the Limits of Economics' (2010) 104 Nw. U. L. Rev. 253, 282-83, for instance, argue that, 'in the absence of a useful economic theory, or a workable metric, the foundations of... [the US and EU approaches towards refusals to deal] are inevitably political, valid for each system on its own terms, and somewhat informative for others, but hardly 'correct' in some provable fashion. ... if economic analysis does not dictate the choice of a legal rule in this area, something else outside of economics must - in other words, something political'.

58 To be sure, scholars at the time elaborated many critiques other than that discussed in the text, notably: (i) the liberal critique of Ronald Dworkin (contesting the equivalence between social interest and the mere aggregation of individual interests, arguing that the latter overlooks the differences among people): R. Dworkin, 'Is Wealth a Value?' (1980) 9 J. Leg. Stud. 191; (ii) the sociological critique of Robert C. Ellickson (observing that individuals who choose for themselves in private transactions are not really conscious of their true interests and values): R.C. Ellickson, 'Of Coase and Cattle: Dispute Resolution 
'existing competitive status quo' that Chicagoan competition law is intended to protect (in this case, by using the 'hands-off approach') is not neutral - it does reflect a mixture of value choices and political decisions. Indeed, competitive equilibrium is not simply 'given', like flowers and electromagnetic forces may be. Each competitive equilibrium results from the combination of many building blocks, such as individual preferences and the willingness to pay, ${ }^{59}$ which are determined in large part by the original distribution of wealth and legal entitlements that, in turn, result from many political choices, social pressures, and legal rules. ${ }^{60}$ Therefore, it cannot be neglected that markets move from, and result in, scenarios that are not value-free and neutral. ${ }^{61}$ As a consequence, if the competitive status quo is not neutral, a fortiori, the

among Neighbors in Shasta County' (1986) 38 Stan. L. Rev. 623; and (iii) the legal realist critique of Arthur A. Leff (focusing on formalism and reductionism as two features of economics that could, as a consequence, create problems once driven into the legal field): A.A. Leff, 'Economic Analysis of Law: Some Realism about Nominalism' (1974) 60 Va. L. Rev. 451.

59 E.g. J. Dewey, The Quest for Certainty (1929) 259, 265, 272-73 (claiming that there is a need for critical reflection on the 'conditions under which objects are enjoyed' and on the 'consequences of esteeming and liking them').

60 E.g. C.R. Sunstein, After the Rights Devolution: Reconceiving the Regulatory State (Harvard University Press 1990) 41-42; C.R. Sunstein, Free Markets and Social Justice (Oxford University Press 1997) 4-5 (observing that in any society, existing preferences should not be taken as natural or sacrosanct'). As a matter of fact, the initial assignment of a right can affect the wealth of the parties, which, in turn, can affect how parties valuate the right as well as the ultimate use of the resource that comes with that right. See further C.E. Baker, 'The Ideology of the Economic Analysis of Law' (1975) 5 Phil. \& Pub. Aff. 3, 13 (arguing that the initial assignment normally affects the relative wealth of the parties. ... In addition, since a person's wealth affects how much that person is willing and able to pay for a specific desired right, the effect on a person's wealth of the initial assignment of that right will influence how much the person "values" the right. In these cases, the initial assignment may determine who "values" the right the most.' See also R.D. Willig, 'Consumer's Surplus without Apology' (1976) 66 Am. Econ. Rev. 589; G. Calabresi and A.D. Melamed, 'Property Rules, Liability Rules, and Inalienability: One View of the Cathedral' (1972) 85 Harv. L. Rev. 1089: 'When a loss is left where it falls in an auto accident, it is not because God so ordained it. Rather, it is because the state has granted the injurer an entitlement to be free of liability and will intervene to prevent the victim's friends, if they are stronger, from taking compensation from the injurer.'

61 Sunstein, Free Markets and Social Justice (n. 60, above) 5, maintains that 'markets should be understood as a legal construct, to be evaluated on the basis 
Chicagoan decision not to modify it is likewise not neutral. The latter is a political choice - to say the least, it is a conservative choice - that, as such, must submit to comparison with alternative options, i.e. with other, more progressive approaches. ${ }^{62}$

To be sure, the Chicago conception of competition law may well choose to protect the status quo without paying any attention to the possibility of changing it. In addition it may also choose - as is commonly recalled - to say nothing about the ways prosperity is used or distributed, arguing that those are matters for other pieces of law.

Yet, in doing so, the Chicago notion of competition law cannot hide the political value of its choices. Notwithstanding the ostensibly neutral and technical set of principles that it uses, the foundations of the Chicago approach are politically determined. More, we cannot believe that these choices are more neutral than the ones underpinning some pieces of economic regulations. Hence, since the reassuring nature of the Chicago conception of competition law is questionable, we cannot use it to justify our alarm towards the alleged regulatory breakthrough of contemporary competition law.

\section{CONCLUSION}

As often happens when we are confronted with complex social phenomena, the boundaries of the definitions that we use to address those

of whether they promote human interests, rather than as part of nature and the natural order, or as a simple way of promoting voluntary interactions'.

62 The so-called 'conservative bias' is just one of the many critiques elaborated against economic analysis and its attempt to reconstruct individual liberalism on market terms. See, in this regard, M. Kelman, A Guide to Critical Legal Studies (Harvard University Press 1987) 114. For an analogous opinion see S. Kelman, What Price Incentives? Economists and the Environment (Auburn House 1981) 27 (observing that, by ignoring the extent to which individuals' values are socially determined, the possibility that institutions can affect the formation of private preferences is neglected). See further, A.T. Kronman, 'Change in the Common Law: Legal and Economic Perspectives' (1980) $9 \mathrm{~J}$. Leg. Stud. 227, 242: 'social institutions, including the law, should be used to mitigate the effects of the natural lottery; for the law to intensify them is perverse. A theory which legitimates the chance effects of the natural lottery treats persons as if they were things by giving moral significance to those aspects of our lives over which we have no control. Such a theory fails to recognize that persons are moral beings precisely because they have a capacity for rational action which puts them, in a limited but important way, beyond the reach of nature's indifferent power.' 
phenomena are blurred. Therefore, in order to understand what we really mean when we talk about the 'regulatory breakthrough' of present competition law, we need to clarify the exact meaning of the terms 'economic regulation' and 'competition law'. This chapter has explored the scope of these two labels and, using two specific forms of economic regulation and competition law as benchmarks, developed two theses. First: we do not err if we argue that competition law acquires 'regulatory contours' whenever its goals, targets, tools and approaches distance themselves from those of the Chicago archetype. Second: the main concerns about this 'regulatory breakthrough' are rooted in a fallacy that, in contrast with economic regulation and any sort of regulatory conception of competition law, only the Chicago archetype guarantees neutrality. In fact, the chapter has shown that the Chicagoan theorization of competition law as well as the Chicagoan recipes to support it are value-laden, just as are any other kind of competition law and any example of economic regulation. 